\title{
Hypermobile and Immobile
}

\author{
Diverse Responses to Protracted Displacement \\ in Ethiopia and Sudan
}

Refugees' onward movement from the first country of asylum in Africa toward further destinations has been a continuous concern for the UNHCR and the international community for at least the past ten years. ${ }^{1}$ However, relatively little research has been done into the reasons for and dynamics of refugees' movements onward from their first country of asylum in Africa. Most of the literature is based on interviews with asylum seekers in Europe who were asked to recount their journeys, but there are two main difficulties with this approach. ${ }^{2}$ First, it does not permit us to account for the many factors that underpin mobility and immobility, being based solely on the narratives of those who succeeded in moving. Second, it does not allow us to move beyond refugees' self-representations and to reconstruct the sociocultural milieus where decisions to move are taken. Also, the few studies conducted in transit countries-usually policy-oriented reports-do not clarify the moral, symbolic, and imaginative dimensions of migrants' choices. As a result, it is generally acknowledged that secondary movements are coping strategies to attain long-term durable solutions, given a paucity of prospects for protection and assistance in the first country of asylum. This is certainly true, but there is more to it.

No doubt, refugees have to face many challenges in the first safe country where they are given protection. Their freedom of movement and their rights to work 
and study are often strictly limited, which in turn limits their chances of longterm legal integration. Yet these structural limitations are not enough to explain why different refugee populations inhabiting the same structural and legal environment adopt different migratory attitudes. What differentiates the mobile ones from those who stay put? Is mobility just a question of access to social and economic resources, or does it also emerge from specific aspirations and moral obligations? How does the aspiration to live elsewhere become a concrete decision to move regardless of the risks? By confronting the desires and daily struggles of different groups of Eritreans in Ethiopia and Sudan, this chapter examines the roles of imagination, emotions, and shared moralities (i.e., ideas about what is moral and immoral, fair and unfair, desirable and undesirable) in relation to mobility and immobility in refugee settings. ${ }^{3}$

First, I compare mobile and immobile refugees whom I met in camps in northern Ethiopia. While accounting for the gap in socioeconomic resources that differentiate those who can move from those who cannot move, I also point to the role of different migratory aspirations. Not unlike my informants in Eritrea, those willing to undertake high-risk migration seemed to share a hierarchy of possible destinations, but others preferred to wait in refugee camps until they could return to their homeland. Second, I describe the daily challenges of urban refugees in Addis Ababa and Khartoum and show how emotional pressure to leave at all costs led many of my informants, even the most indecisive, to take the decision to move onward.

\section{THE RUSH TO DEPARTURE}

December was a month of preparation and departures in the camps. Many were waiting for the end of European winter. Several houses in the peripheral areas of the camps had been left deserted, and those refugees left behind were relocating toward the center of the settlement close to the hospital, schools, and places of entertainment. Reaching Khartoum in January-February was believed to be ideal for organizing the next step of the journey. Among my informants in the camp, several were negotiating with their relatives abroad to make sure they would support their journeys; others were asking around the camp to find the cheapest and most trusted middleman. At night big trucks destined to be loaded with migrants traversed the dusty roads of the Adi Harush and Mai Aini refugee camps. ${ }^{4}$

Shimelba, Mai Aini, Adi Harush, and Hitstats are the four main camps where Eritreans end up in Ethiopia after crossing the troubled, heavily militarized border (map 4). After a few months in Addis Ababa trying to get permission, ARRA, the government Agency for Refugees and Returnees Affairs, finally authorized me to visit these camps around the area of Shire. Juggling between my previously established informal contacts among Eritreans in the camps and the need to comply 




FIGURE 6. Shimelba, the oldest Eritrean refugee camp in Ethiopia (photo by the author, 2013)

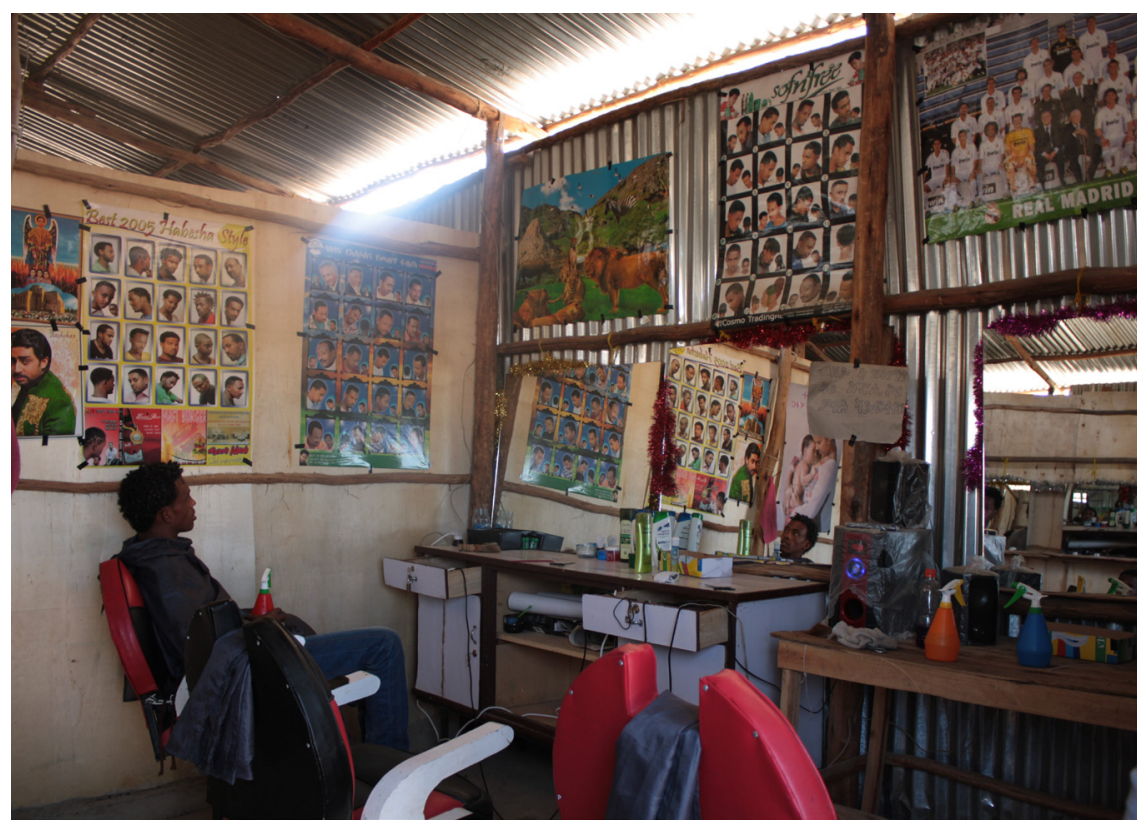

FIGURE 7. A barbershop in Hintsats camp (photo by the author, 2013) 
with the formal requirements of ARRA (see Appendix), I spent a month observing, interviewing, and sharing some of the daily life of the refugees in the four camps. ${ }^{5}$

Located in an extremely hot, dry, and remote region, these camps were certainly challenging environments for settlement, but they were not necessarily worse off than the surrounding areas. Living conditions, infrastructure, and service could vary significantly among the camps, depending on the number of agencies active in the camp, humanitarian investments, and the date the camp had been established. ${ }^{6}$ However, these camps, veritably big towns, ${ }^{7}$ were usually relatively well served in terms of schooling and health status and health provisions and were blossoming with small business (informal banks, food stores, hairdressers) and recreational activities (cinemas, bars, and restaurants) established by refugees themselves. Safety was also not an issue there. ${ }^{8}$ Yet the inhabitants of these camps, with the exception of those in Shimelba, strongly desired to move on to other destinations-mostly in Europe, the United States or Canada. ${ }^{9}$

The insufficiency of the rations, lack of monetary assistance, and the exhausting search for firewood were constant challenges there. ${ }^{10}$ The crucial problem, however, was getting out of the camps and working. They had to seek permission to exit the camp, and employment was in any case limited and mostly irregular. ${ }^{11}$ Many engaged in different livelihood activities, such as breeding animals, farming the land, working as daily laborers in the camp surroundings, setting up small businesses, and serving humanitarian organizations as interpreters, community workers, or teachers. However, what they earned only covered basic subsistence and did not allow them to help their families back home; nor did it provide them with the means to construct a viable future for themselves and their children outside the camp.

"What is the difference between dying slowly here in camps," said Jacob, a twenty-six-year-old engineering graduate in Adi Harush. "Or dying while crossing the sea? If we have to die, it is better to do it trying to reach Europe rather than wasting time here far away from our homes and without the possibility of constructing a future!" As the camp population mostly consisted of young, entrepreneurial men, ${ }^{12}$ sometimes with university-level educations, it is easy to understand how, in their eyes, a life in the camp was untenable.

Refugees there felt stuck in a condition of social liminality-unable to fulfil family obligations as well as cut off from a recognized social status among their peers, families, and the society at large. Jacob's association of a life in camp with a "slow death" reflects the concept of social death discussed in chapter 1 with respect to my informants who felt left behind in Eritrea. Not unlike them, my respondents in the camps perceived themselves as immobile in time and space, caught in a meaningless loop of daily activities and constraints, which did not allow them to help their families, become adults, and realize their dreams.

As local integration is restricted, and repatriation sounds to the majority like a remote and unappealing solution, most individuals in the camps strongly desire to be included in a resettlement program. But this option is only for a few. In 2013 , 


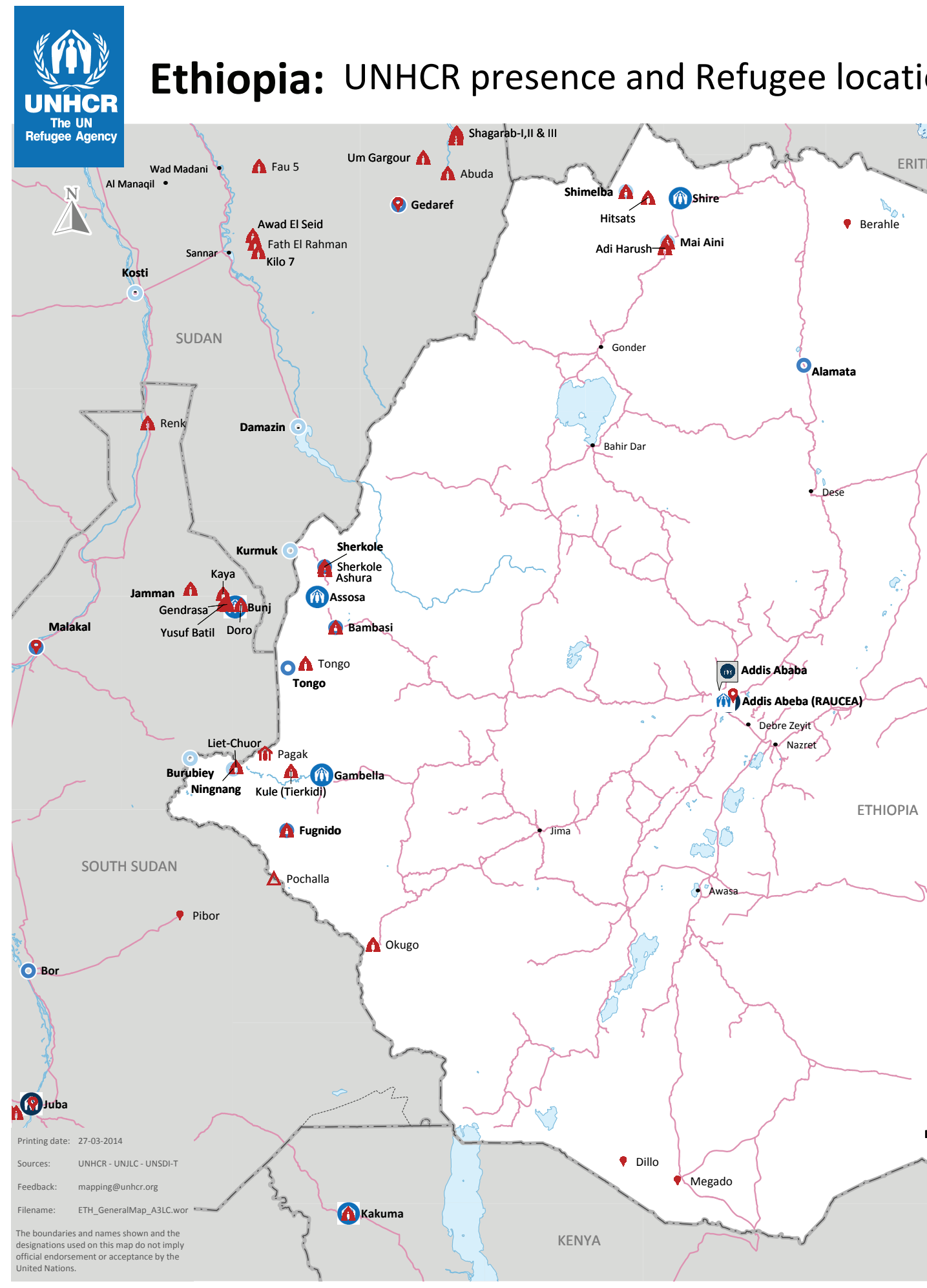

MAP 4. Refugee camps in Ethiopia (UNHCR 2014) 


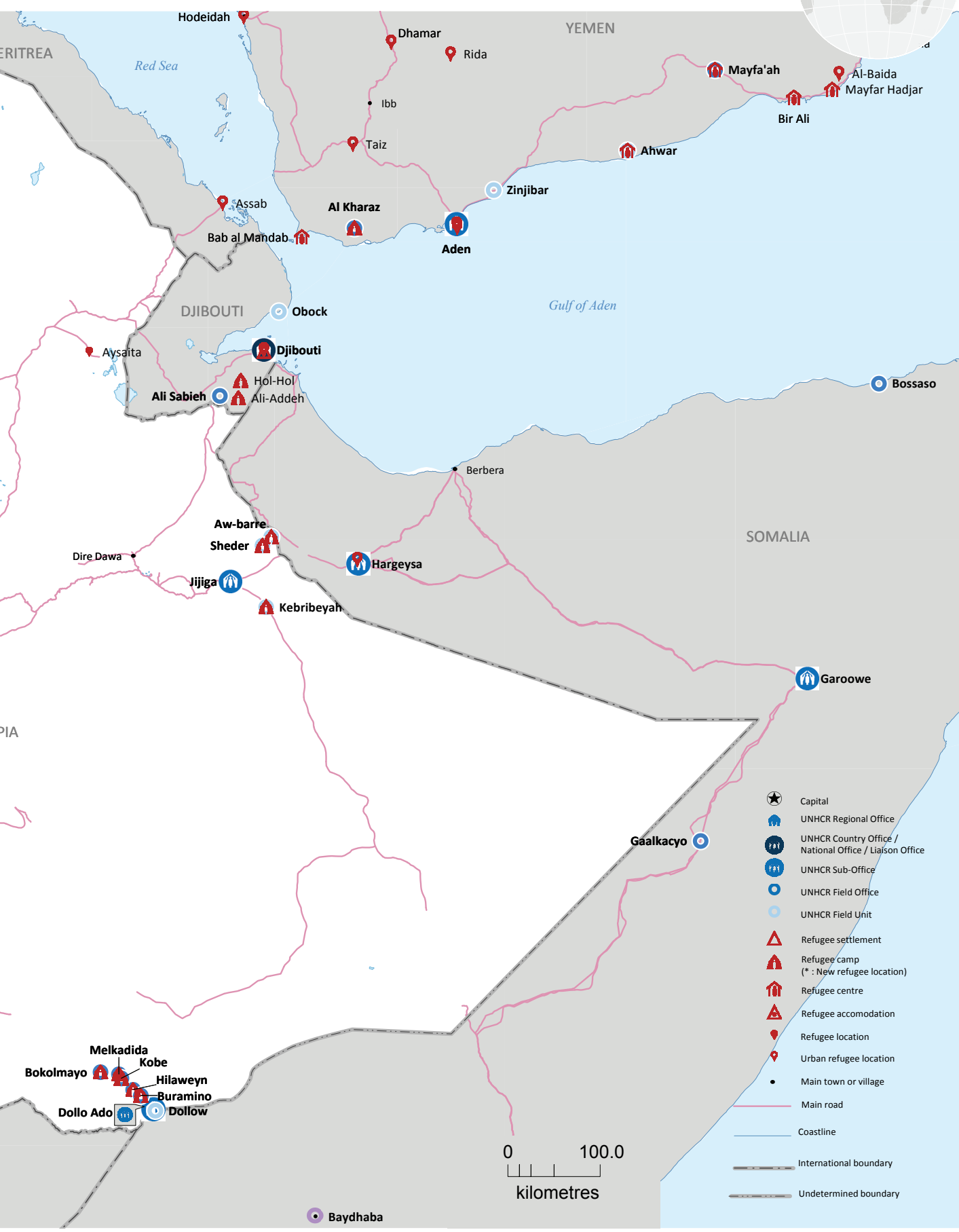




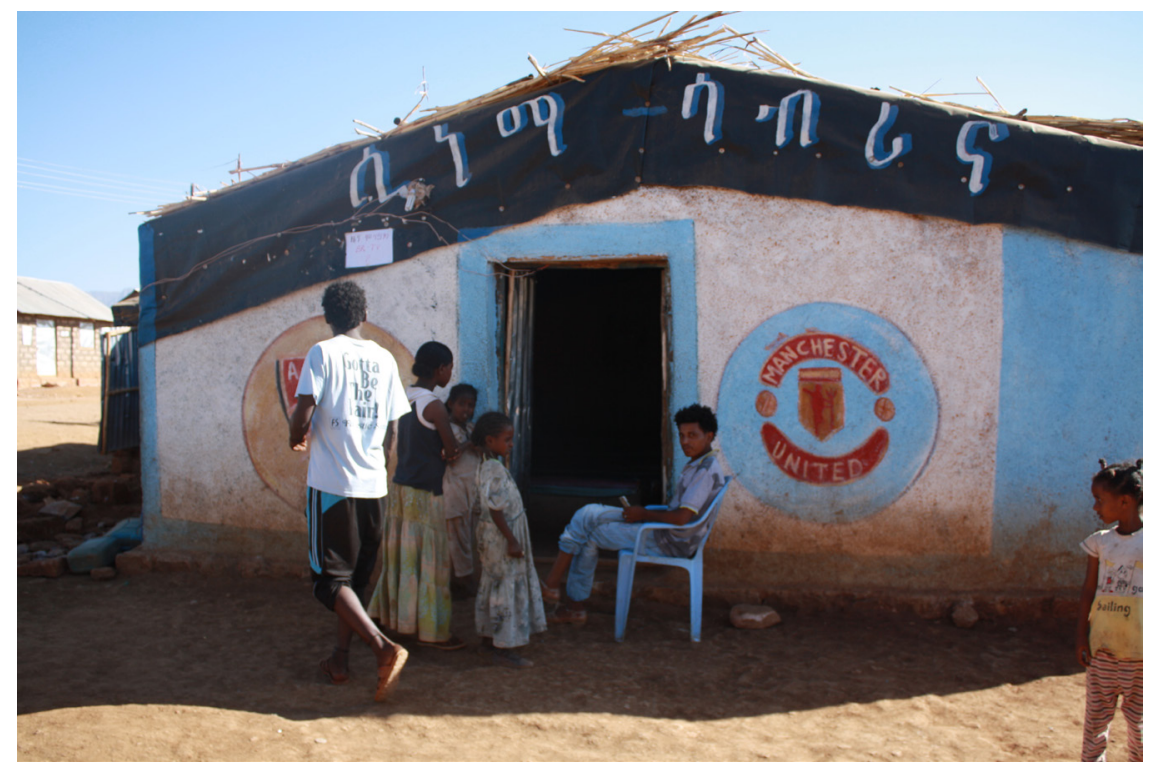

FIGURE 8. Cinema in Adi Harush camp (photo by the author, 2013)

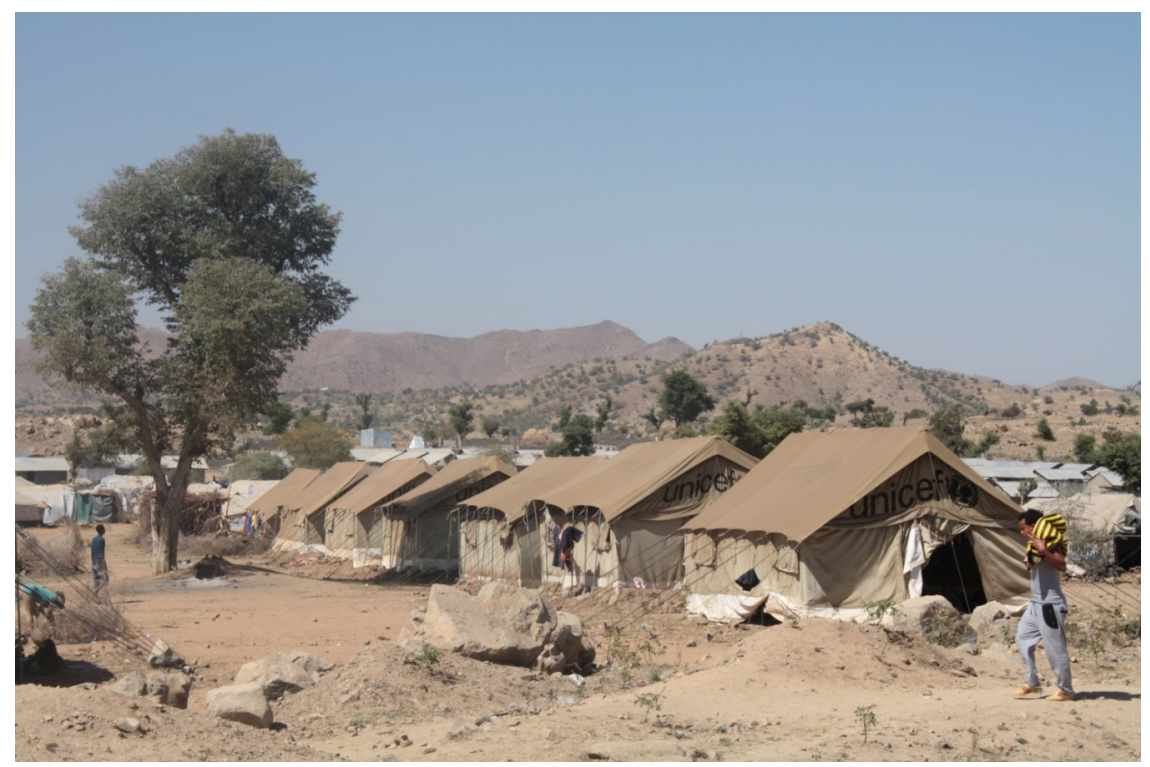

FIGURE 9. Hintsats, the most recently established camp (photo by the author, 2013) 
according to the UNHCR officers I interviewed in Shire, only 850 individuals were resettled-less than 1 percent of the Eritrean refugees in the country. This is in line with international resettlement rates. ${ }^{13}$ Refugees are usually referred for resettlement only if they had been in the camp for over ten years or if they can be included in the category of especially vulnerable cases according to UNHCR guidelines. ${ }^{14}$ Given these poor odds, many refugees were planning to resort to smugglers with the financial backing of relatives in the diaspora. Without their resources, migration to Europe is mostly unattainable. ${ }^{15}$ Relatives' help is secured by transnational moral economies, which prescribe that those who are abroad support their leftbehind kin. Migration is one of the main cases in which this support is required, and the determination of young Eritreans to move no matter the risks compels even unwilling helpers to comply with it. The availability of transnational family networks is thus crucial to understand who can and who cannot move from the first country of asylum. The large Eritrean diaspora explains why Eritreans have been able to migrate more than other refugee groups.

Many resided in camps only for the time needed to organize their trips to Libya. Almost all of the respondents in the small survey (of twenty-six households) I conducted in Adi Harush to investigate secondary movement expressed a desire to migrate onward. ${ }^{16}$ The others simply seemed too helpless to express an opinion at all. Those who mentioned the United States and Canada were usually men and women who hoped to get there through some kind of family reunification visa or resettlement. The ones who answered Europe-usually young single men set to depart soon-mainly referred to Norway and Sweden as intended final destinations. ${ }^{17}$ These were perceived as particularly favorable for refugees in terms of social assistance and prospects for employment. Southern European countries, like Italy, were never mentioned and nobody seemed to consider a life anywhere in Ethiopia, even outside the camp, as a possible long-term solution.

Although most people I met seemed to aim to move on as soon as possible, strategies could also differ depending on the gender of my interviewees. Femaleheaded households often included more than one family, as women tended to assist each other in childcare and to share the few resources they had. These women had often given birth either shortly before or shortly after arriving in the camp. They were usually waiting for reunification with their husbands who had left the camp trying to reach Europe. It was a common strategy among refugee families to diversify migration options. ${ }^{18}$

Not unlike my young informants in Eritrea, the young refugees whom I interviewed in camps shared a hierarchical vision of the world. Their desires to move to some countries instead of others mirrored their classification of places and their inhabitants along a ladder of legal stability, developmental achievements, moral worth, and socioeconomic prospects. Rather than seeing them in the context of a generalized "culture of migration," we can better understand their aspirations by 
referring to the idea of cosmologies of destinations, which allows us to consider the specific imaginaries and moral prescriptions attached to different destinations. The desire for mobility did not target the "West" in general, but rather specific locations within it.

Onward migration was an omnipresent topic of discussion and a pervasive practice in the camps. The households of young male refugees in particular seemed characterized by a continually shifting population. In Abraha's hut, for example, everyone wanted to leave soon. One of my refugee friends in Addis Ababa had given me Abraha's phone number and asked him to take care of me during my stay. After a tour of the camp facilities, he took me to his mud house. His housemates were four men in their late twenties and early thirties, coming from Segeneiti, a Catholic town in southern Eritrea. One of them was lying in the bed trembling with high fever due to malaria-which was endemic in the camps-but the other three spent some time chatting with me.

Mascio was around thirty years old. He had been in Sudan before and then tried to reach Israel, but on the border he was caught by Egyptian police and imprisoned for four months before being sent to Ethiopia. When I met him, he told me that he was tired of waiting in the camp: after a year and seven months there, it was time for him to try his luck again. This time he wanted to reach Europe. Jeremy, the other housemate, had a sister and a brother in Norway. He was waiting for them to send him money to cross the Mediterranean, and in the meantime he was breeding a small family of goats, which kept peeking through the front door. Abraha had relatives abroad, too: a brother in Canada who was going to sponsor him and a sister who had just moved from Italy to Switzerland in search for better opportunities. After being in the camp for over a year, Abraha did not seem willing to wait longer for his siblings to take action. A few months later I discovered that he had started his journey to Norway through Sudan. The stories of Mascio, Jeremy, and Abraha mirrored a widespread determination to move regardless of the risks. Often this determination emerged from a deeply felt obligation to left-behind kin who were waiting for their economic support.

Movements out of the camp were continual, but this does not mean that many individuals had not been in the camps for very long time. In Shimelba, the oldest Eritrean camp in Ethiopia, I met men and women who had been living there for over ten years, hoping to be resettled for lack of alternatives. Also in Adi Harush I met many refugees who had been there since the establishment of the camp in 2010. Of the 26 households I interviewed, three said they could not go anywhere, because they did not have relatives abroad to pay for their journey. Their livelihood strategies in the camp were evidently different from those who were not planning to stay long. They strove to be self-reliant. One of them, for example, was raising chickens to sell to the local market to support his young wife and baby; another family had set up a tea shop in the camp. Many of them were from poor 
rural areas in southern Eritrea, not far from the Ethiopian border. It is likely that their journeys to Ethiopia had not been very expensive.

This brings back the issue of forced immobility. Lacking resources, longtime residents in camps, the most deprived of all, could not even afford to live in Addis Ababa. They had no other choice but to hope that a resettlement officer would consider their cases. Having been obliged to flee Eritrea, they were now obliged to stay in Ethiopia, forming "trapped populations." ${ }^{19}$ However, not everybody had been obliged to remain. Some had chosen to do so.

\section{THOSE WHO CHOOSE TO STAY: THE CASE \\ OF THE KUNAMAS}

Most scholars emphasize how legal constraints, deprivation, and limited social resources lead to immobility among refugee and migrant populations. However, even in the most extreme situations, such as those of refugees in camps, one should not simply assume that everyone would like to migrate on. Sometimes, immobility can be a choice, reflecting personal aspirations and communal moral values. In the context of Eritrean migration, the Kunama ethnic minority from Shimelba is a significant counterpart to those who would do anything to move on.

In 2006, the United States offered to resettle around 6,000 Eritreans from Shimelba. The Kunama ethnic minority was the target group. Ethnically persecuted in Eritrea, ${ }^{20}$ they closely fit the definition of refugees according to the 1951 Geneva Convention. However, something completely unforeseen happened: more than half of the Kunamas-2,80o out of 4,00o-refused to be resettled, declaring that they preferred to stay in the camp, waiting to go home as soon as Eritrea became a peaceful place again. Eritreans from other ethnic backgrounds-mostly Tigrinya, the largest ethnic group in Eritrea-started to be resettled instead. When I reached the camp in December 2013, the population of the camp (about six thousand) consisted mainly of Kunamas who had refused resettlement, recent arrivals, and a small number of Tigrinyas whose resettlement cases had been rejected or delayed.

I was quite puzzled when I found out about the rate of refusals among the Kunama refugees. Hitherto I had only met Eritreans-mostly Christian Tigrinyas-who were trying their best to get out of Ethiopia and in the absence of a resettlement case or a family visa, they were ready to embark on dangerous border crossings. Why, then, did Kunamas refuse the opportunity to be resettled? My encounters with refugees, NGO workers, and UNHCR officers in Shimelba helped me to figure out some of the main factors behind this unprecedented response.

My Kunama translator for the occasion was Noah, the twenty-six-year-old son of Bartholomeus, an evangelical preacher. ${ }^{21}$ His religious activity as well as his refusal to give up his land to Tigrinya settlers had made him and his family a target 
of Eritrean authorities. Noah's mother was the only member of the family who had stayed back home, and Noah and his brother were both in the camp waiting for resettlement. They, unlike other Kunamas, believed that resettlement to the United States was the best option. This had put them in conflict with other members of the community who discouraged resettlement. Their huts had been set on fire more than once, and the father always secretly traveled from Shire, Shimelba, and Addis Ababa so as not to become an easy target or endanger his family.

Among those who opposed Kunamas' resettlement in the camp, there was the Democratic Movement for the Liberation of Eritrean Kunamas (DMLEK), an opposition front active in Shimelba since the early 200os. DMLEK had depended on the population of the camp for taxes and recruits, and group resettlement was a serious threat to its existence. Its militants had therefore spread the rumor that those going to the United States would be badly treated and sold as slaves. To reinforce the fear of America, the 1970s TV series Roots-narrating the misadventures of Kunta Kinte, an African slave in America-was screened in the camp. Moreover, Kjetil Tronvoll and Daniel Mekonnen, who were present in the camp in 2008, reported on DMLEK's recurrent threats. ${ }^{22}$

DMLEK was evidently not alone in fiercely opposing the Kunamas' resettlement, however. While doing my fieldwork in Shimelba, I was secretively informed by some of my informants that I should be careful about inquiring too deeply into the resettlement issues. According to them, some local officers were selling the identities of Kunama refugees accepted for resettlement to Ethiopian nationals.

Aside from the above pressures, other sources reported that Kunamas were scared of resettlement because of their unfamiliarity with urban living. The department responsible for cultural training in the resettlement program since 2007 , noted that many Kunamas were "not familiar with most modern amenities, they have a fear of the apartments in which they'll live in the United States. Most specifically, they have a fear of fires in these apartments." Last, but not least, many of the Kunamas had left loved ones in Eritrea, and going to the United States would put an insurmountable distance between them. Resettlement was perceived as treason to their family members and community traditions. Old people were usually more determined in their decision to stay, and their younger relatives did not want to leave them behind.

Nana, an old Kunama lady whom I met in Shimelba, told me she had no interest in going to the United States, shaking her head. She and her family came from Bimbinna, a conglomerate of villages on the southern side of the Gash River. They had fled to Ethiopia in 2000 because of the war, she said, but her sisters had stayed behind. She was receiving remittances from her two sons in the United States, but she was not interested in going there. Many other Kunamas repeatedly said they did not want to resettle because part of their family was still in Eritrea. This was 


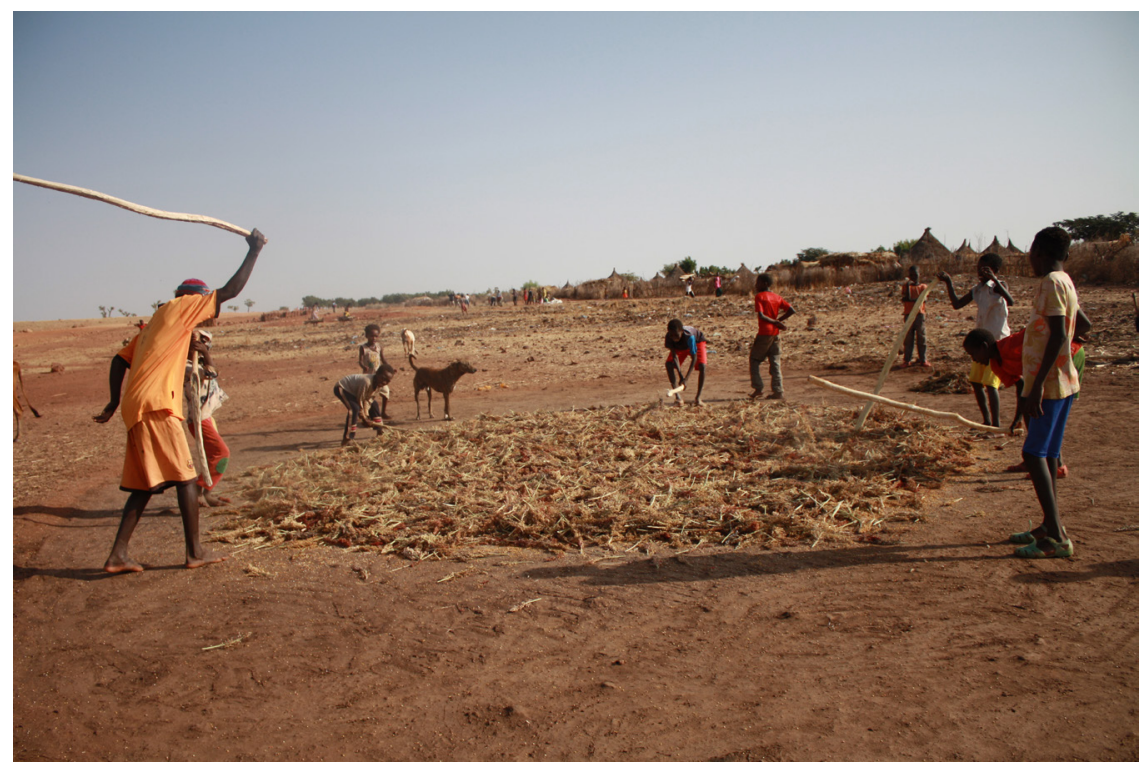

FIGURE 10. Kunama refugees threshing teff (Eragrostis abyssinica) in Shimelba camp (photo by the author, 2013)

especially the case for those who reached Ethiopia in 2000 and had since then started to rebuild their lives in the camp. ${ }^{23}$

Older Kunamas' attitudes to migration were embedded in a completely different cosmology of destinations to that of the refugees I had met before. The United States was not considered an attractive place, but rather a place to be scared of, precisely because of its modernity and distance from the cultural and material world with which Kunamas were familiar. The return to the homeland, on the other hand, was portrayed as the only desirable way ahead. The homeland was the repository of positive values, and return there was felt as a moral obligation.

Besides having less historical exposure to international migration in comparison with the urbanized Tigrinya population, Kunamas tended to have a stronger relationship with the land, like most indigenous people around the world. ${ }^{24}$ As the Kunama scholar Alexander Naty has showed, Kunamas' religious and cultural life is rooted in the landscape of southwestern Eritrea. ${ }^{25}$ Without falling into unnecessary cultural reifications or wanting to fix people's identity in a specific place, it seems undeniable that the strong relationship between people and their land is also crucial in analyzing their aspirations to migrate elsewhere. ${ }^{26}$

Just as the Hutus studied by Liisa Malkki in Tanzanian refugee camps rejected local integration to preserve their long-term dream of returning to Burundi, ${ }^{27}$ Kunamas also refused resettlement in order not to give up their imagined future 
at home. Not unlike the Hutus, they felt that migration would contribute to the loss of their "identity," the bundle of memories, practices, and relationships that connected them with the natural landscape and social fabric of their homeland. However, things had started changing for them too.

\section{SONS AGAINST FATHERS: EMERGING GENERATIONAL DIVIDES}

Although most Kunamas had refused to resettle in 2008, I quickly realized while in the camp that many had changed their minds. Those Kunamas who were only children at the time of the group resettlement proposal were now young men and women eager to move to the United States in spite of their parents' opinions. However, resettlement is a family process, and these generational differences were generating many tensions within families. Often young Kunamas remained stuck in the camp because their cases had been frozen because one of their parents having refused the resettlement in the first place.

A tall, shy-looking young boy sat down close to me while I was interviewing a group of Kunama men. I did not even notice him until Noah said, "Why don't you talk to him? His story is interesting; you should listen to him." Jambo lived in a poor hut with his three sisters, his aunt, her boyfriend, and her children. Jambo's mother had died, and he did not have a good relationship with his father, so the aunt had taken care of him since childhood. She came to greet us holding and nursing her baby. We sat in front of the hut, and Jambo started telling me how eager he was to go to the United States. The problem was that his aunt and his father had refused resettlement at first and their family case had been archived as a rejection. Even though Jambo was now nineteen, his case was linked with his father's case, who was still determined not to leave the camp.

Jambo's story was not an exception in the camp; rather it was the instance of a common conundrum, which the UNHCR resettlement unit had a hard time solving. In UNHCR's perspective, family unity is a principle to be protected-the opportunity for resettlement should not become the cause of family disintegration. For this reason, the group resettlement in 2008 was organized through family cases. However, the refusal to resettle as well as different positions inside the nuclear family had not been anticipated in UNHCR operations, and even now, many cases remain frozen.

Aside from their practical-and tragic-implications, Kunamas' shifting attitudes to resettlement can be interpreted as an instance of how migration progressively comes to be seen as an appropriate livelihood strategy in a community with little previous experience of it. Due both to exposure to processes of cultural circulation and progressive estrangement from the homeland, young Kunamas were gradually developing a preference for migrating on rather than waiting for an unlikely return back home. The feedback of the pioneers who accepted the reset- 


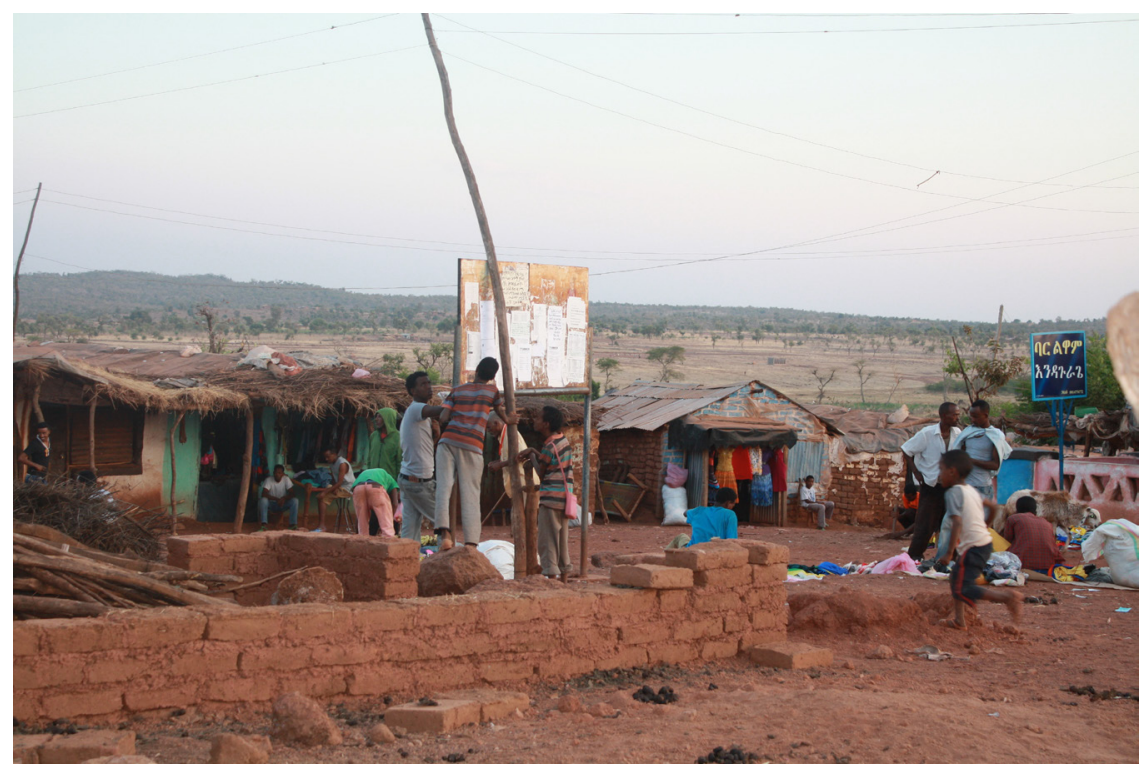

FIGURE 11. Resettlement board in Shimelba (photo by the author, 2013)

tlement, the impact of their remittances in the lives of those left in the camp, and the wider exposure of the young generations to Western lifestyles had inevitably transformed the projects of many. Instead of going back to a home that they have almost forgotten or never even seen, most young Kunamas are now searching for a home elsewhere. Unlike their Tigrinya counterparts, however, those Kunamas I encountered were not ready to pursue migration at all costs.

I often asked those among the Kunamas who were interested in migration if they had ever thought about reaching Europe irregularly. Their usual reaction was a bewildered look, as if I had asked something ridiculous. "It is illegal, we cannot do it," one of them told me. Another man in his thirties, who had been telling me how desperate he was to leave the camp, said: "It is very dangerous! Don't you know that people die in these journeys?" These answers were surprising to me, since for the other Eritreans, illicit migration was almost a given. No matter the dangers or the legal implications, other Eritrean refugees living in similar conditions as the Kunamas in Shimelba were ready to run all risks to reach Europe. Irregular-undocumented-onward migration ${ }^{28}$ was common, almost the norm in all the camps, with the exception of Shimelba. What determined such a difference between these groups?

Part of the answer lies in the different structure of opportunities available to Kunamas. While Tigrinyas had a well-established network of relatives abroad to support their journeys, and a large number of friends and acquaintances along the way to Europe, Kunamas' family and ethnic networks were less developed in the 
diaspora. ${ }^{29}$ Moreover, only a few Kunamas had the financial means to move forward by themselves, and they were not familiar with the idea of doing so. It seemed that, in spite of the emergence of a new desire to migrate among the younger generations, mobility at all costs had not (yet) become the norm for them, unlike for other Eritreans I had previously met. Perhaps mobility based on a cosmology of destinations may emerge as a second phase after the diffusion of a more general culture of migration. While in the latter, mobility is a widespread orientation, it is not yet perceived as a moral duty. My research in urban areas of the Ethiopian and Sudanese capitals aimed at exploring the normative aspect of mobility among those who are determined to leave at all costs.

\section{SEEKING WAYS OUT FROM ADDIS \\ ABABA AND KHARTOUM}

Refugees in Ethiopia and Sudan - the main recipient countries up today-officially have no freedom of movement or right to work outside the camps, but there are large urban refugee populations in both Addis Ababa and Khartoum..$^{30}$ According to official UNHCR statistics, there were 3,500 Eritreans in Addis Ababa in 2014. ${ }^{31}$ Roughly 2,500 participated in the Ethiopian government "out-of-camp" scheme, many of them students at Ethiopian universities. ${ }^{32}$ Besides these registered urban refugees, there were also many other Eritrean refugees living in the city. Some, after six months in the camp, could obtain permission to stay in Addis to follow up on their visa application, while others had short-term permission to visit their relatives. Many simply stayed in the city without permission..$^{33}$

The situation in Khartoum, the Sudanese capital, is similar. Since the late 1970s, Khartoum has hosted a substantial population of both Ethiopians and Eritreans (around 33,000 in 1981 according to Ahmed Karadawi). ${ }^{34}$ According to official UNHCR statistics, there were around 20,000 Eritrean refugees in Khartoum in 2014. ${ }^{35}$ The actual number is probably much higher, considering the number of individuals who do not register with UNHCR or the Sudanese government's Commissioner of Refugees (COR). ${ }^{36}$ A continuous flow of people leave Sudanese camps to settle in the city on their own-either to work or to look for migration opportunities. Unlike Ethiopia, Sudan does not have any out-of-camp policy and the only refugees allowed to live outside the camp are those who are vulnerable and included in the UNHCR protection program. All the others who live in the city usually have no legal right to reside there.

Although in Khartoum as well as in Addis Ababa I interviewed a wide variety of stakeholders, ranging from diplomatic officers to United Nations High Commissioner for Refugees and the International Organisation of Migration workers, I spent most of my time hanging out with Eritreans in different settings of the two cities. My first contact in Addis Ababa was with an Eritrean nun I had known since my first visit in the country in 2011. Originally from the village of 
Mai Nefas, Sister Kudussan had been living in Addis Ababa for over twenty years. Unable to return home because of wars and diplomatic tension, she was stuck in a country she had had been brought up to hate. She managed a convent and its associated breeding farm on the periphery of the city. When I went to meet her, I soon realized that her convent had become a meeting point for young, usually Catholic, refugees from Mai Nefas and the surrounding villages. Many of them were waiting for their family reunification visas so as to be reunited with their husbands or wives. The convent thus became one of the main places where I could meet young refugees and participate with them in religious festivities or simple coffee ceremonies.

In parallel, I used to hang out with a group of Eritrean students from the University of Addis Ababa. Most of them in their late twenties or early thirties saw few prospects of remaining in the country. Their Ethiopian degree was in fact not enough to allow them access to the regular labor market. Among them was Adonay, a twenty-eight-year-old philosophy student, whose story I tell later.

In January-after my research in the camps-I moved to Mebrat Haile, one of the neighborhoods most inhabited by Eritreans in Addis, with Violetta, who had been a practicing physician in Eritrea before escaping with her uncle, Gaim, to Ethiopia. Overwhelmed by the work conditions, Violetta had managed to convince her uncle, who was a soldier in the border area, to escape. She was hoping to get a sponsor visa from a relative in Canada. When I met her in November, she was twenty-seven and living with her uncle in a one-room flat in Mebrat Haile. Her uncle was soon to leave for Khartoum, however, and she was happy to share the rent with me for a few months. Violetta became not just my flat mate but a valuable informant and a friend. Smart and fluent in English, Violetta was my translator in several occasions (see Appendix).

Our neighborhood was filled with Eritrean refugees. Many of them just managed small internet points or pool rooms; others were just living there waiting for the opportunity to move on. Our time was marked by house visits to our neighbors and friends. Many people I knew lived there: Alazar's family had recently moved there, other friends and relatives of those I had met in Eritrea and Italy were also staying there. Even members of some of the families I had met in Adi Harush waved to me on the streets.

In March, many of my informants from Eritrea and Ethiopia moved to Khartoum, and I decided to follow them. For example, Hagos, the spokesman for the group of Eritrean refugees at Sister Kudussan's convent, moved with his cousin to Aljiraf, a neighborhood in Khartoum traditionally populated by Eritreans. Lwam had left and reached Sudan in that period, and Violetta's uncle was there working as a badjaj (three-wheel taxi) driver. However, not all of them seemed keen to meet me again. Lwam did not contact me and I did not manage to meet Violetta's uncle, despite my efforts to do so. I believe that the reason why they avoided meeting me was not per- 


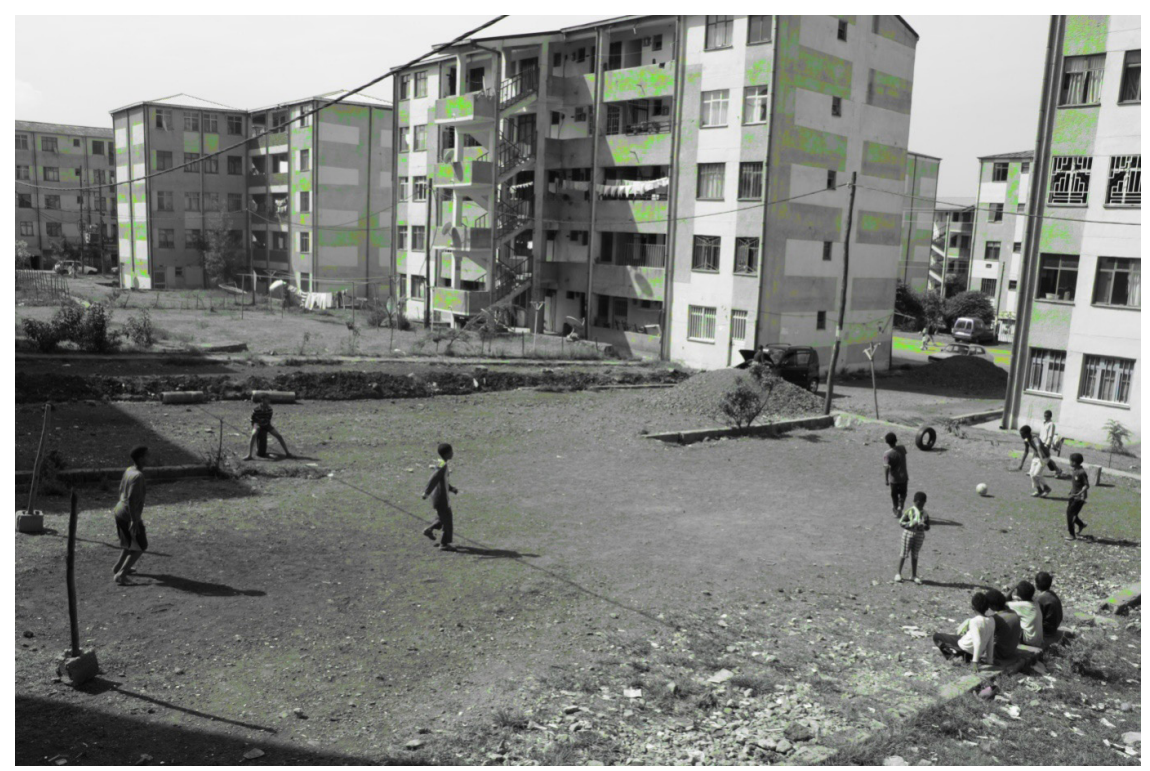

FIGURE 12. Mebrat Haile: an Eritrean neighborhood in Addis Ababa (photo by the author, 2014)

sonal antipathy, but rather the fear that I might somehow disturb their plans to move on. Lwam, for example, contacted me only when she had safely reached Germany. Maybe they thought that, being in touch with their families, I might reveal their plan to leave the country to their relatives and make them worry. Maybe they believed that I would have tried to persuade them not to undertake that journey.

In Khartoum, I lived with Maria, a twenty-eight-year-old Eritrean and her eight-year-old child, Anna, in a house shared with other four Eritrean families in the Jabah area in March-April 2014. Violetta had explained to Maria that I was a researcher, asking if she could help me to settle in the city. She guaranteed that I was a decent flatmate with no special expectations and that I could help with the house expenses, so Maria generously accepted me. Maria had lived for several years in Addis Ababa before recently moving to Khartoum. As she told me, one of the main reasons she had left Ethiopia was because Anna's father was cheating on her. Her departure to Khartoum, however, was only thought as a temporary step on the path to further destinations. I spent most of my time with Maria, her neighbors and friends from Asmara.

Along with Eritreans, in both cities I had friends among the locals who helped me with the practicalities of life in a new country. I often tended to mix my Eritrean and local networks while going out in the evening or spending some leisure time together. This was for me a natural way of dealing with people who were close to me, but often these interactions gave rise to conflicts that I did not at first anticipate. The interactions between refugees and locals that I cre- 
ated with my presence in the field, however, allowed me to grasp some of deeprooted mistrust and prejudices that separate Eritrean refugees from Sudanese and Ethiopians.

Although Khartoum and Addis Ababa present different challenges and opportunities for Eritrean refugees, in both places I found a constant desire to move on among my informants. As I show in the following section, this desire to move onwards is certainly the result of both the limited access to the local labor market, and the need to attain some kind of legal existential stability. However, the drive to migrate further also emerges from deep-rooted moral obligations toward left-behind family members and the imaginaries surrounding destination countries. These are continually reproduced in the relatively segregated places inhabited by Eritrean refugees in these two cities and generate a sort of collective effervescence, which provides fertile ground for embarking on dangerous border crossings.

\section{ROUND-UPS AND THE RISK OF DEPENDENCY: CONTINUITY OF LIFE STRUGGLES BEFORE AND AFTER EXILE}

After a three-hour Sunday mass, Maria and I found ourselves in the middle of a police round-up. We were just coming out of the Catholic Church of St. Peter and Paul in the center of Khartoum. Suddenly, the crowd started to get agitated. "There are policemen ready to take us when we exit the church," murmured an old woman with eyes full of fear. "They have already taken someone." Maria started to become nervous. "I cannot come to church anymore. It is too dangerous . . . now what do we do?" Some refugees were organizing a hamjad - a minivan-to pick them up at the entrance of the church. I went out to look for a hamjad to avoid the risk of Maria and Anna being arrested, and we got home safely.

In Khartoum, police round-ups are common and especially feared by refugees. Those who are apprehended without papers-but sometimes also those who have papers-are incarcerated, usually blackmailed in exchange for money and, sometimes, returned to camps. Eritreans call these round-ups geffa, the same word used to identify the round-ups in Eritrea to catch draft-dodgers. The need to run from police and authorities is one main element of continuity in the lives of Eritreans before and after their migration.

Round-ups were certainly among the top reasons why life in Sudan was considered unsafe and undesirable by my informants. They often told me of run-ins with Sudanese police and their attempts to pass unnoticed in order not to be harassed. "To be unnoticed" mainly entailed for men not to wander alone at night in unknown places, not to drink too much, and to follow the Muslim dress code (long sleeves and long trousers). For women, it meant wearing a long, black jellabiah (traditional Muslim dress) and head scarf as local women do. 
Police controls were less common in Addis Ababa. However, while I was there in November 2013, my informants told me that the Ethiopian police were knocking on doors in Mebrat Haile to check refugees' permissions to be out of the camp. These controls were probably a consequence of rioting in the Tigray camps a few weeks before. ${ }^{37}$ And even so, living an "unnoticed life" was easier for Eritreans in Ethiopia. Not only is Tigrinya spoken in Ethiopia, but Tigrinya Eritreans resemble most Ethiopian highlanders (Amharas, Tigriyans, and Oromos) and have both their religion and cultural elements such as food and traditional clothing in common with them.

Besides avoiding authorities, the biggest problem for those living in cities was dependence on relatives abroad. Once they leave the camp, refugees are usually not entitled to any assistance. UNHCR and other humanitarian organizations provide only limited support to a small number of refugees considered to be in special need. Thus, many Eritreans I met had to rely on their relatives' help for their daily living expenses. This was especially true in Addis Ababa, where finding work was harder. For example, Violetta had an uncle in Denmark paying her rent and sending her some money every two months. Likewise, Alazar's family received regular support from Minia's sons in Israel and Canada. My informants who were students at Addis Ababa University would have not been able to survive without the assistance of some relatives abroad, even if they received a small allowance and did not have to pay for tuition and accommodation.

Protracted dependence on relatives abroad was perceived as shameful, especially by young men, who acquire a status depending on their ability to provide for others. Like those young Eritreans stuck back home, the young refugees I met in Addis Ababa and Khartoum felt caught in a condition of socioeconomic, generational, and existential immobility.

Obtaining work in Ethiopia was generally deemed hard among refugees. Government control was tight and employers often asked for ID cards before hiring. Eritreans who could speak Amharic, or who had relatives or other connections in Addis Ababa, were more successful in finding work. Self-employment was tolerated and internet cafes and pool rooms managed by Eritreans kept popping up in Mebrat Haile during the months I spent there.

Although Khartoum was probably considered less safe, the job market seemed more accessible for refugees there. In Sudan, it was usual to find Eritreans employed as waiters, cleaners, and cooks. Many of them managed restaurants and other businesses in the name of a Sudanese national in the area of Jiref and Aldeim-historical Habesha neighborhoods in Khartoum. Some of Maria's neighbors worked in factories and workshops, while others owned rickshaws or minivans used as taxis. The Eritrean women I met-Maria too, for a short period-were employed as domestic workers. ${ }^{38}$

In spite of the challenging environment, these instances of informal integration and, at times, successful businesses illustrate that alternatives to onward mobility 
do exist. However, even those among my informants who seemed to do okay in Addis and Khartoum felt obliged to embark on life-threatening journeys to reach Europe rather than investing more in their present lives there.

Families back home were worried if their sons and daughters were in Ethiopia or Sudan. The refugees themselves perceive themselves in transit and those relatives abroad-like my informants in Italy-felt the pressure of helping them get to Europe or other developed countries. I used to insist with my closest Eritrean friends, like Maria and Adonay, that life in Addis Ababa and Khartoum was not so bad after all. Even if the challenges were many, I thought that it was worth looking for an informal job and starting a new life there, since options for leaving the country were either too risky or not accessible, but they believed that there had been no point in leaving Eritrea only to end up staying in Ethiopia or Sudan.

\section{IMAGINING THE FIRST WORLD FROM A MALL IN KHARTOUM}

Anna, Maria's eight-year-old daughter, had been impatient the whole day. Her mother was at work and I had been left to take care of her. "When is mom coming back?" Anna kept asking me. "Are we going to Afra?" Afra was a huge modern mall, not far from Khartoum international airport. Anna had never been there and probably had no idea of what it was, but from the way it had been presented to her, it sounded like a good place. During the day she had been boasting with the other children in the compound, "I am getting ready to go to Afra today ... Milena and I will go there in the afternoon. You don't know what Afra is? Really?!?? Ahaha!" The other small children looked at her with their mouths open in admiration.

Afra was an oasis in the desert. The building, sheathed in shiny black glass, resembled an Arabic royal palace built of pinkish stone and surrounded by palms and fountains. Inside, vivid signs touted expensive shops selling international luxury goods. To pass from one floor to the other, we had to use the big escalators. It was Maria's first time on the escalator. "Anna nei-come! Give me your hand! Milena hold me, please!" Maria pleaded in a frightened voice. Our common friend, Michael, led us to a kind of pizza hut for dinner. We all ordered food, but Anna was too excited to eat; she wanted to go and play in the recreation room that she could see on the corner. After the pizza we ran around after Anna in the recreation room, full of trampolines and big inflatable balloons. "It's the first time I've seen Anna so happy," Maria said.

When we finally managed to drag Anna out, night had fallen on the city and the bright colors of the mall lights hid Khartoum's poverty. Maria exclaimed jokingly: "Oh! This is Italy, not Sudan! Afra is Italy and we have been to Italy today!" Michael then cynically pointed out the poor surroundings of the mall: "but all around us is still Sudan ..." 
Maria's ingenuous image of Italy-I believe she mentioned it more than another European country only for the sake of pleasing me-cannot certainly be generalized. Imaginaries are intrinsically and above all personal representations, although they also reflect collective views of reality. ${ }^{39}$ In this case, Maria's association of the mall with Italy reflected an imaginary widely extant among many of my informants in Ethiopia and Sudan. Similar to what has been documented in African and other contexts, the mall, as the prototypical symbol of consumption, has come to represent modernity as a complex bundle of political and social freedom, technological advancement, and happiness. ${ }^{40}$ In Maria's cosmology, the mall was a crucial feature of life in Europe, and she saw it as being somehow out of place in Sudan, a country which she despised for its lack of freedom, its dirtiness, its religious distance, and poverty.

Once home, while braiding Anna's hair before going to sleep, Maria energetically told her: "Anna, pray to our beloved sweet Jesus Christ, pray that one day you, Milena and I can all go to Italy . . . always pray, never forget it, ok? Good girl!" But there was never enough money, and Maria was also scared of the risks along the journey. However, the thought of providing a better future for Anna tormented her day and night. Her exhausting search for a way ahead, however, emerged not only from a desire for modernity, but also from a social milieu characterized by high levels of self-segregation, and socioeconomic and cultural homogeneity.

\section{STICKING TOGETHER ...}

All of the dwelling arrangements I visited, whether in Addis Ababa or Khartoum, mirrored Eritreans' perception of being in transit, and their need to consolidate and build up their social resources by living together with their compatriots. Urban refugees tend to concentrate in the same neighborhoods and share accommodation among themselves. However, the areas inhabited by my informants were not ghettos: they were not especially destitute neighborhoods, and they were populated by refugees and locals alike. For example, Mebrat Haile, where I used to live in a one-room flat with Violetta, was a lower-middle-class neighborhood. It covered a whole valley with huge grey condominiums, which, by local standards, are modern, desirable accommodation. Most Eritrean refugees I met lived there, along with Ethiopians. Several groups of four or five shared a one-room flat with a single toilet, while others stayed in cheaper accommodation in other areas.

In Khartoum, the neighborhood where I lived with Maria and her child was mostly inhabited by Sudanese (but we also had several Eritrean neighbors) and was not particularly deprived. Other Eritreans lived in the traditional Habesha area of Aldaim or around Aljiraf and Al-Shafa, where there had been Eritrean 


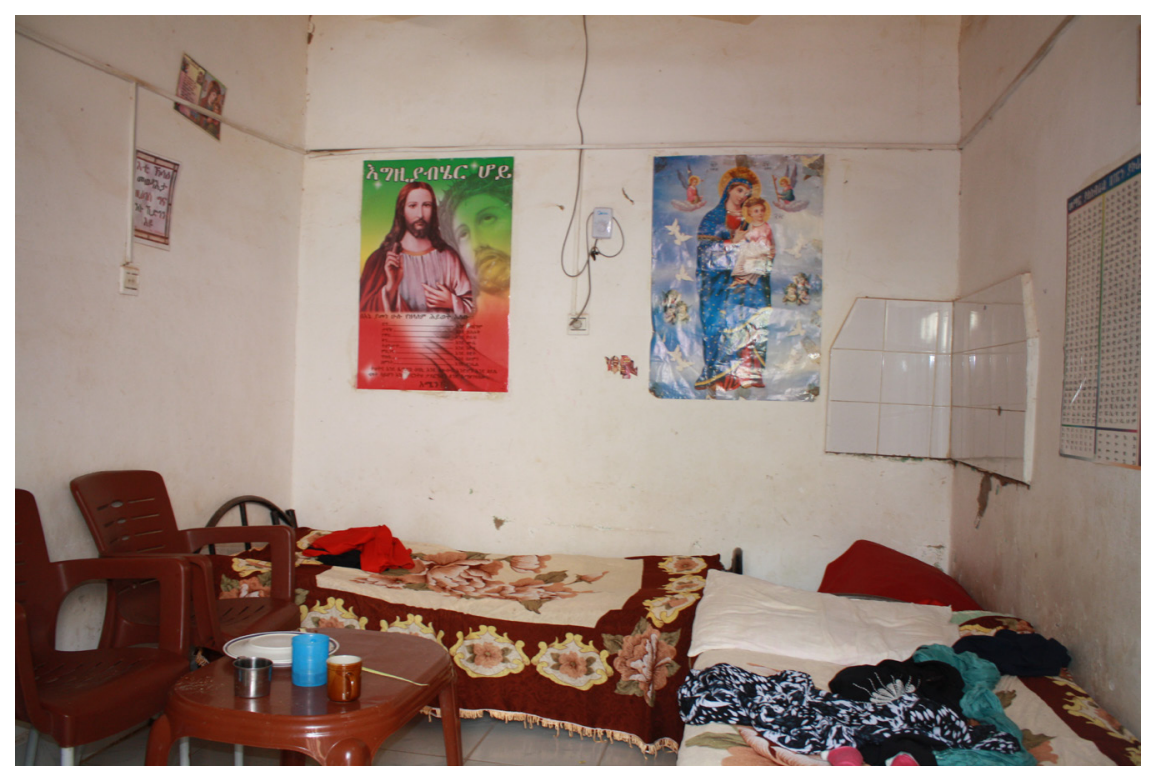

FIGURE 13. Typical Eritrean accommodation in Khartoum (photo by the author, 2014)

schools for refugee children since the 1980 os and there were now recreational centers. Although our neighbors were mainly locals, our compound was exclusively inhabited by Eritrean refugees. A couple who worked in a soap factory by day and made sandals at night lived in front of Maria and Anna's one-room apartment. Istifanos, the husband, had managed to collect enough money to reach Sweden in June, while his wife waited for him to send her the reunification visa. Thirty-yearold Jennah and her two children lived behind us, waiting for reunification visas to join the father in Sweden. In front of Jennah lived an old woman with her silent sixteen-year-old nephew, who moved to Libya in less than a month. Finally, next to Istifanos's room, there was Haile's extended family. Most of them were waiting for family reunification visas to join their partners in Canada. and the others were looking for options to follow them.

Other refugee houses that I visited in the city were also socioeconomically and ethnically homogeneous. These enclaves were not only emerging from the need to support each other in a challenging environment. They were also the result of mistrust between Eritreans and local populations. Interethnic relations between Eritreans, Sudanese, and Ethiopians are embedded in a decades-long history of power imbalances, religious diversity, and political and national conflicts. It is crucial to gain insights into the stereotypes that characterize those relations in order to understand Eritrean views on Sudan and Ethiopia and why they do not represent viable destinations. 


\section{... WHILE DISTRUSTING OTHERS}

Many of the Eritrean refugees I met all throughout my fieldwork depicted Ethiopians as lazy, cowardly, and uneducated, often referring to them as Agame, people from northern Ethiopia who used to work as low-status laborers in Eritrea in the past. ${ }^{41}$ These stereotypes were created in opposition to self-representations of Eritreans as loyal, hard-working, brave, and educated. In issues concerning refugee procedures and associated complications, Ethiopians were often described as corrupt, envious of Eritreans and of the possibility of their being resettled elsewhere. Although commonalities with Ethiopian highlanders are acknowledged, as denoted by the self-denomination Habesha, ${ }^{42}$ the social distance between the two groups seems wide. This becomes evident when looking at the perception of a suitable marriage: for many, having a daughter marry an Ethiopian would be a great misfortune. This is a concern especially because, in Tigrinya patrilineal society, children will take the name, the nationality, and their ethnic belonging from the paternal lineage.

Conversely, Eritreans were mostly depicted as conceited and arrogant by Ethiopians, who treated them with a paternalistic attitude. Violetta often had to endure comments from my Ethiopian friends, who, while intending to show their solidarity to her as an Eritrean sister, somehow insulted her pride. One of the first things they would say after they discovered she was Eritrean, was: "Oh you are our sister; Eritreans and Ethiopians are the same people, it is just because of dirty politics that we are separated and your people are suffering." Although this was meant to be friendly, it did not sound quite that way to Violetta, proud as she was, like most Eritreans, of the struggle for independence.

While Ethiopian and Eritrean identities are constructed as opposed, ${ }^{43}$ yet united by a set of recognized physical and cultural commonalities, Eritrean and Sudanese people were seen as incommensurably different. Even before getting to Sudan, my Eritrean friends told me never to trust Sudanese. When I got to Sudan, I discovered that Sudanese often represented the reification of all evils in my informants' eyes. Maria, for example, thought that Sudan was filthy and that Sudanese people were not trustworthy. She hated the lack of freedom in the country, symbolized by the requirement to wear the veil and the long black Muslim dress.

These negative beliefs translated into Maria's daily practices. She invariably looked for an Eritrean taxi driver, saying: "Let's get a Habesha one. I don't like Sudanese." Maria said it was very easy to distinguish Sudanese from Habesha: according to her, the latter were cute and slim, while the former were fat with ugly faces. However, this categorization was clearly unrealistic. Once, one of my Sudanese friends, Ismael, a twenty-six-year-old graduate from Khartoum University, took me home. He was tall and slim, with a clean and kind face. Maria happily approached him in Tigrinya: "Are you Habesh?” Ismael replied in Arabic: “No, I am from here." Maria was very surprised to realize that Sudanese were not so dif- 
ferent from Habesha in the end, but she kept disapproving of my friendship with Ismael anyway. ${ }^{44}$

In turn, as I realized during several conversations with taxi drivers, shopkeepers, students, and guides, Habesh were also seen rather negatively by many Sudanese. My sponsor in Sudan, a businessman in his thirties, bluntly expressed his doubts about me living with Eritreans instead of renting a hotel room: "Habesh people do not have prestige; they are not intelligent. We, the Sudanese, feel they are inferior to us. Why do you want to live with them?"

Some of the stereotypes characterizing Eritreans' interactions with locals in Sudan and Ethiopia are remarkably postcolonial. This is evident in the continuous comparison between the "cleanliness" and beauty of Asmara with the "dirtiness" of Addis Ababa and Khartoum..$^{45}$ Although partly resulting from colonial discourse, the complexity of interethnic relationships between Eritreans, Sudanese, and Ethiopians also emerges from precolonial conflicts and recent social history. Reciprocal fears, mistrust, and negative judgments cannot be understood without considering the thirty years of war against Ethiopian rulers, the forced displacements of thousand families from Ethiopia in 1998-99, and the difficulties historically experienced by Eritreans in Sudan. ${ }^{46}$ Religious interpretations (such as the veto on Muslim women marrying Christian men) and other culturally shaped gender attitudes can be added to explanations based on social and economic stratifications. ${ }^{47}$

The above considerations are necessarily simplifications of a much more nuanced and larger range of attitudes marking interethnic relations in both countries. However, they provide a rough idea of widespread prejudices, which may increase an already existing segregation of urban refugees, while strengthening their self-identification as a group in transit. Living together with little or negative interaction with local populations reinforces Eritreans' feeling of being there only temporarily, while longing for other destinations. Within this sociocultural and legal context, it is not surprising that an emotional status comparable to what Émile Durkheim called a "collective effervescence" emerges in periods when structural opportunities for (irregular) mobility open up.

In The Elementary Forms of Religious Life (1912), Durkheim describes the collective feelings generated in the rituals of Australian Aborigines and argues that through this "collective effervescence," societal moral order as well as individual belonging to it was renewed and reinforced. ${ }^{4}$ The mobility practices as well as the mobility-related discourse continually reproduced in the shared dwelling places of my informants were strengthening the moral and eschatological order implicit in their cosmology of destinations.

\section{SPRING FEVER IN ADDIS ABABA ...}

"Egi bahari tsobok [now the sea is fine]" and "Egi serghie tsobok [now the road is good]" were common statements in the conversation among my friends and 
neighbors in Mebrat Haile. As the European winter was finishing and spring was at the door, the neighborhood was effervescent in anticipation of the departure of many of its inhabitants. These statements were not simply words in the air, but declarations of intent. Between February and March, more than half of the people I knew had left Mebrat Haile to go to Sudan and from there, crossed over to Libya and then to Europe. Even many of my friends in Eritrea, such as Lwam and Valentina, moved in that period to go to Sudan (Lwam arrived in Italy soon afterward).

March is the right month, according to popular wisdom there, to start the journey from Sudan to Libya. The Sahara desert is not too hot and the waters of the Mediterranean Sea will be calmer by April than during the winter. Many people I used to hang out with called me from Sudan to give me their news; others just disappeared, and I found out about their departure only long afterward. The ones who had remained wondered if they had made the right choice, or simply kept trying to get enough money to follow their companions to Sudan.

In the evenings, the internet cafés were still full of young people, but conversations and interlocutors had changed. Since I started living in Mebrat Haile, Violetta and I used to spend long hours in Amanuel's internet café trying to connect with our families or simply listening to Amanuel-the twenty-nine-year-old Eritrean manager-playing krar, a traditional lyre. Before March, I noticed those sitting close to me chatting with their families and friends in Eritrea through Yahoo messenger and Facebook or video-calling their relatives or partners in Europe or the United States. In March, conversations were more often with friends who had left Mebrat Haile and reached Sudan: "Temesgen hawey, denhando? Sudan Kemmei? [Temesgen my brother, how are you? How is Sudan?]” A group of young boys from the neighborhood gathered in Amanuel's internet point to talk to their friend in Khartoum and kept joking with him on skype: "Now you have to speak Arabic, bro, how are you managing?"

In that period Violetta and I often went to our favorite juice shop. Once, while we were waiting for our juices, a young Eritrean man started to talk to Violetta. "Are you one of us?" he said in Tigrinya. "Yes, I am," answered Violetta with a smile. "How did you know?" "I can see it from your face. You are an Asmarina [a positive term to define someone who grew up in Asmara]!" The two started chatting. Dani was twenty-seven and also from Asmara. "I am leaving to Libya soon, but I am scared," he said quietly, and then more resolutely continued. "I don't want to go, but I have no choice. I have no process [i.e. visa application] here, ${ }^{49}$ unless your ferengi friend marries me"-giving me a sarcastic look. "One of my brothers is in Switzerland, the other has just made it to Norway . . I have to go." Not only the fear of the risky journey, but also the anxiety of being left behind in the run for Europe was clear in Dani's words.

In that period, even those Eritrean refugees who had told me that they did not want to take risks to get to Europe became convinced that the moment was 
right. Amanuel, the internet point manager, for example, had told me about his plan to join some of his friends in Angola, but one evening in late February, coming back from a night out, I overheard him saying to Violetta in Tigrinya: "Now the sea is calm. I have decided to go to Europe. I am planning to leave in a few weeks." He explained that all his flat mates had already left. He reached Norway two months later.

Even Adonay, the philosophy student at Addis Ababa University, changed his mind around then. Since I had met him, he had been asking for my help to get a scholarship to a European university, but never seemed really to have Europe as his goal. "Have you heard what happened in Lampedusa last October?" he would say. "No, no, the risks are too high . . that is not for me." Then his plans abruptly changed in March. One night I received a message from him: "Milena! I will depart for Sudan tomorrow. I will keep in touch with you."

I was amazed; the week before, we had proofread one of his last essays before his master's thesis and he seemed determined to finish his degree in Ethiopia. Why had he changed his mind? Worried about losing the opportunity at least to say goodbye, I phoned him, asking, "What happened, Adonay?" "Sorry, Milena-he replied-These journeys are very risky, I did not want to tell you. But nowadays these journeys can be profitable; the way through Libya is open and there is good rate of success."

We decided to meet in the Italian-built neighborhood of Piazza a few days later. Adonay looked worried in his tidy but worn-out button-down shirt. While we were sipping coffee from the terrace of a café, he kept touching his head and was nervously laughing while explaining to me about the uncle who was supposed to pay for his journey.

"But why, Adonay, did you change your mind? You said it was too dangerous!" I asked him. "I have been a burden for my family-he responded-At this age I should be able to provide for myself. At least. Yeah, yeah, it is not good, to become so miserable. I have been waiting here for very long, now it's time to risk. If I die, I will die, that's it."

The difficulties in finding jobs, shame at not being an independent man, and the desire to migrate to a more suitable destination had been the ingredients of Adonay's life for a while, but they had now become unbearable. Whereas all his friends, classmates at university and relatives were moving on, Adonay's prospects had not changed. Immersed in the emotional atmosphere of anxiety and departure characterizing Eritreans' dwelling spaces in those months, Adonay's carefulness about risks turned into determination to migrate at all costs. However, his plans were never realized. His uncle was not ready to pay, but instead promised to help him establish some kind of business in Addis. Unfortunately, the uncle died a few months later, leaving Adonay without support-either to migrate or to start a new life in Ethiopia. 


\section{... AND IN KHARTOUM}

When I moved from Addis to Khartoum at the end of March, I found that even there, Eritrean refugees seemed to be affected by "the fever of leaving." Maria's place was a buzz of continuous coming and going of Eritrean refugees, especially on Sundays. Maria would sit in front of her small stove and start preparing coffee while kindly entertaining her guests. No matter what the topic started as, it would not take long before all conversations shifted to the usual question: "Nski process allo?"-Do you have a process?

Some of Maria's guests were lucky: they had managed to apply for a sponsor visa to Canada thanks to the help of some relatives there; others had found a husband or a wife somewhere who could grant them a reunification visa. Everyone was going to leave soon. Even those who did not have money for the smugglers were determined to leave. Rahel, one of Maria's guests, told us that she and her husband did not have money, but were planning to ask the smugglers to take them to Libya and from there, one call here, one call there, and with God's help, someone would pay. "After all," Rahel said. "Libya is closer to Europe than Khartoum, isn't it?"

The coffee ceremony in Maria's house was somehow a collective ritual in which mobility-related norms were reproduced and the longing for onward migration was elicited..$^{\circ}$ This could also eventually lead to attempting irregular migration or simply to frustration at the inability to move, as in Maria's case.

"I would really like to go to Libya," Maria sighed after a phone call announcing that a friend and her baby had made it to Italy. "But I am too scared for Anna and I do not have money. People told me that if you do not have money, the smugglers rape you. I heard of one girl who has been raped by five men!! But Europe would be good for Anna ... I would like her to study in a college and to learn English well."

Although Maria's past has remained a mystery for me until now (at first she told me she had no close family members, but then I received a call from her brother in the United States) it was clear that she did not have relatives ready to pay for her journey-otherwise, I believe, she would have moved then. The meager salary from her cleaning job-which anyway did not last for long-did not allow for daily survival and the smugglers' fee to reach Libya. Out of the 500 Sudanese pounds a month (about $€ 50$ ), she paid 380 in rent, and the remaining money was barely enough for food-not even sufficient to send Anna to school. This brings us back to the conditions that produce immobility even in the presence of strong aspirations to migrate. Maria's case illustrates again how capabilities to move are stratified according to socioeconomic status, gender, and the ability to mobilize resources from one's own informal network of family and compatriots. ${ }^{51}$ However, the availability of resources is not enough to make sense of refugees' determination to move on. Maria's aspirations to live in the First World and to provide a better future for Anna were continually reproduced by these social gatherings where all her guests talked about how and when to go. 
"The road is great now," Seare, one of our usual guests, used to repeat confidently. "Nowadays there are no problems at all! You should go Maria! Don't be scared! Anna is big now ... there are a lot of women who are still breast-feeding, but are already crossing the sea! Italians patrol the sea with helicopters, and ships come to fetch the refugees in the middle of the sea." ${ }^{2}$

"Yes," Maria muttered. "But we have no money." At this point the conversation would often turn to the role I could possibly play as Maria's helper.

Visitors would ask if I could provide her with a legal invitation to come to Italy or if I could pay for her journey across the Mediterranean. Sometimes they would ask Maria in Tigrinya, while on other occasions guests were more direct. Seare was extremely insistent. "What can you do for them? Take Anna with you then Maria will come by boat. I know one friend who can help us. If you pay the money then everything will be ok. Why are you scared? Now there is no problem!"

Although I told Seare that I did not agree with the journey, he kept insisting until I lost my temper and told him I was not ready under any circumstance to pay for such a risky trip. But these encounters left me wondering what my role as researcher was and what ethical principle I should have applied at that time (see Appendix). After these visits, Maria was often troubled. One time, she could not sleep and we stayed up for a while, chatting. "Milena, I am always thinking ... where will Anna and I go?" she said. "How will we manage? My God . . . all our neighbors have some kind of process or some money, but I do not have anything. I always think I must be honest-if I am honest God will like it and He will open the way for me and for Anna. But I think too much, so sometimes, I start cleaning the room, I clean and clean and then I feel better." Most of the time I felt powerless in the face of all her difficulties and suffering. I told Maria that I was going to help her to send Anna to school, but her expectations were much higher.

After my departure from Sudan. I kept in touch with her, as with most of my closest informants, and helped her send Anna to school. We decided together that Ethiopia would be an easier place to settle for them. They had Ethiopian passports, so Maria could work and Anna could peacefully go to school. I asked one of my Italian friends in Ethiopia to look for employment for Maria and soon thereafter, Maria found work as a cleaner in two Italian houses that provided a good income. They found a room close to Anna's school and for a few months everything seemed to proceed smoothly. Then I received a call from Maria saying that she wanted to leave again to go to Sudan. Life was hard in Addis, too. Her husband had come back home, but he was still behaving badly, and Maria could not bear him. After a month, I received her call from Sudan. She said she wanted to go to Libya and take Anna with her. She wanted me to pay. I refused, saying that the situation in Libya was too dangerous. Our conversation left us both disappointed. I am sure she thought I was a stingy, ungrateful Western woman, and I thought she was a careless Habesha woman. Then, the news reached Maria that a boat with seven 
hundred people on board had sunk in the Mediterranean (April 20, 2015), which slowed down her plans to cross over to Europe. However, her restlessness has not ceased, even now. After that, she decided to go back to Eritrea-apparently it was safe for her to do so. Then, a few months later, she went back to Sudan. The last time I talked to her, she was asking me for help to move to Ethiopia again.

Maria's frustrated desire for mobility points to the strength of collective imaginaries, moral attitudes, and communal emotional energy surrounding the search for a new home among refugees in transit. Although the availability of money and the capacity to mobilize it through one's own networks is crucial to understand who moves and who does not, the determination to move at all costs reflects the power of shared moral expectations associated with migration and the widespread belief that these cannot be met in countries like Sudan and Ethiopia. Moralities, imaginaries, and emotions are not only relevant for interpreting the flow of migration from Ethiopia and Sudan, but also-and arguably even more so-in analyzing secondary movements within Europe. 